Abstracta Iranica Abstracta Iranica

Revue bibliographique pour le domaine irano-aryen

Volume 26 | 2005

Comptes rendus des publications de 2003

\title{
History and coin finds in Georgia, Sasanian coin finds and hoards. (Moneta, 30), Wetteren 2003, 96 p., 16 pl.
}

Karin Mosig-Walburg

\section{(2) OpenEdition \\ 1 Journals}

\section{Édition électronique}

URL : http://journals.openedition.org/abstractairanica/3508

DOI : 10.4000/abstractairanica.3508

ISSN : 1961-960X

Éditeur :

CNRS (UMR 7528 Mondes iraniens et indiens), Éditions de l'IFRI

\section{Édition imprimée}

Date de publication : 15 mai 2005

ISSN : 0240-8910

Référence électronique

Karin Mosig-Walburg, " History and coin finds in Georgia, Sasanian coin finds and hoards. (Moneta, 30), Wetteren 2003, 96 p., 16 pl. », Abstracta Iranica [En ligne], Volume 26 | 2005, document 173, mis en ligne le 08 décembre 2005, consulté le 25 septembre 2020. URL : http://journals.openedition.org/ abstractairanica/3508; DOI : https://doi.org/10.4000/abstractairanica.3508

Ce document a été généré automatiquement le 25 septembre 2020.

Tous droits réservés 
History and coin finds in Georgia, Sasanian coin finds and hoards. (Moneta, 30), Wetteren 2003, 96 p., $16 \mathrm{pl}$.

Karin Mosig-Walburg

Recueil des trouvailles de monnaies sassanides faites en Géorgie.

INDEX

Thèmes : 3.2.3. Séleucides, Parthes et Sassanides

\section{AUTEURS}

KARIN MOSIG-WALBURG

Université de Francfort 